\title{
Large-scale gene flow in the barnacle Jehlius cirratus and contrasts with other broadly-distributed taxa along the Chilean coast
}

\author{
Baoying Guo ${ }^{1}$, John P Wares ${ }^{\text {Corresp. } 2}$ \\ ${ }^{1}$ College of Marine Science and Technology, Zhejiang Ocean University, Zhoushan, Zhejiang, China \\ 2 Department of Genetics and Odum School of Ecology, University of Georgia, Athens, Georgia, USA \\ Corresponding Author: John P Wares \\ Email address: jpwares@uga.edu
}

We evaluate the population genetic structure of the intertidal barnacle Jehlius cirratus across a broad portion of its geographic distribution using data from the mitochondrial cytochrome oxidase I (COI) gene region. Despite sampling diversity from over $3000 \mathrm{~km}$ of the linear range of this species, there is only slight regional structure indicated, with overall $\Phi_{\text {ст }}$ of $0.036(p<0.001)$ yet no support for isolation by distance. While these results suggest greater structure than previous studies of $\mathrm{J}$. cirratus had indicated, the pattern of diversity is still far more subtle than in other similarly-distributed species with similar larval and life history traits. We compare these data and results with recent findings in four other intertidal species that have planktotrophic larvae. There are no clear patterns among these taxa that can be associated with intertidal depth or other known life history traits. 
1 RH: Phylogeography in Jehlius cirratus

2 Large-scale gene flow in the barnacle Jehlius cirratus and contrasts with

3 other broadly-distributed taxa along the Chilean coast

4

5 Guo B. ${ }^{1,2}$

6 Wares J. P.*2

7

$8{ }^{1}$ College of Marine Science and Technology, Zhejiang Ocean University, Zhoushan, Zhejiang,

9 China

$10 \quad 2$ Department of Genetics, University of Georgia, Athens, Georgia, USA

11

12 *corresponding author: John P. Wares, University of Georgia, jpwares@uga.edu 


\section{Abstract}

15 We evaluate the population genetic structure of the intertidal barnacle Jehlius cirratus

16 across a broad portion of its geographic distribution using data from the mitochondrial

17 cytochrome oxidase I (COI) gene region. Despite sampling diversity from over $3000 \mathrm{~km}$ of

18 the linear range of this species, there is only slight regional structure indicated, with overall

$19 \Phi_{\mathrm{CT}}$ of $0.036(\mathrm{p}<0.001)$ yet no support for isolation by distance. While these results suggest

20 greater structure than previous studies of J. cirratus had indicated, the pattern of diversity

21 is still far more subtle than in other similarly-distributed species with similar larval and life

22 history traits. We compare these data and results with recent findings in four other

23 intertidal species that have planktotrophic larvae. There are no clear patterns among these

24 taxa that can be associated with intertidal depth or other known life history traits. 


\section{Introduction}

26

27 A persistent question in marine biogeography and population biology involves the

28 interaction of species life history, geographic range, and trait or genealogical diversity

29 within that range. In some cases, genealogical diversity or "structure" (Wares 2016) within

30 a species is informative of mechanisms that act to limit other species' distributional ranges

31 (Brante et al. 2012; Dawson 2001; Riginos \& Nachman 2001; Wares et al. 2001). Of course,

32 these studies often find that organisms with limited larval or juvenile dispersal have

33 greater amounts of structure and less extensive ranges, but there are often exceptions

34 (Marko 2004). It is the variation among species, and the exceptions to the "rules", that offer

35 continued opportunity to understand marine diversity.

36

37 Early approaches to comparative phylogeography (Dawson 2001; Dawson et al. 2002;

38 Hugall et al. 2002; Stuart-Fox et al. 2001; Sullivan et al. 2000; Wares 2002) focused

39 primarily on regions of co-diversification of intraspecific lineages, e.g. the regions across

40 which species were likely to exhibit structure. Subsequently, Marko (2004) noted that even

41 when species had apparently identical life history and dispersal mechanisms, the

42 distribution of a species across habitats (e.g. intertidal height) could influence their

43 persistence in distinct glacial refugia. However, certainly to understand these associations

44 more taxa should be compared, and Kelly and Palumbi (2010) made explicit comparisons

45 of diversity and population divergence for 50 species along the Pacific coast of North

46 America to suggest that species high in the intertidal were perhaps more likely to exhibit

47 spatial genetic structure than those at lower depths. However, within taxa that are more 
48 closely related, e.g. among barnacles, this rule does not necessarily hold. Along the Pacific

49 coast of North America, the high intertidal Chthamalus dalli exhibits no apparent

50 population structure (Wares \& Castañeda 2005) relative to the mid-intertidal Balanus

51 glandula (Sotka et al. 2004), while other barnacle species in this region also show

52 effectively no structure (Dawson et al. 2010).

53

54 The particular spatial structure of the species represented in Kelly and Palumbi (2010)

55 varies; however, there is often concordance of population structure - a non-random

56 distribution of population discontinuities - among groups of species (Pelc et al. 2009; Small

$57 \&$ Wares 2010) on this coast. Other regions that have been similarly explored - for

58 example, the NW Atlantic coast - have fewer instances of strong population structure aside

59 from regions that are also recognized as biogeographic transitions (Altman et al. 2013;

60 Díaz-Ferguson et al. 2009) among more distinct groups of taxa. Another such example of

61 this concordance of genetic diversity with biogeography was recently published by Haye et

62 al. (2014), looking at species with short-dispersing larval forms around the well-

63 characterized biogeographic transition near $30^{\circ} \mathrm{S}$ latitude along the coast of Chile. Again,

64 the structure of diversity within species was informative to the mechanisms - including

65 shifts in upwelling intensity and nutrient availability (Navarrete et al. 2005) - that may

66 limit the distribution of other taxa. As patterns of coastal upwelling are associated with

67 phylogeographic structure in many regions and species (Rocha-Olivares \& Vetter 1999;

68 Zakas et al. 2009), it merits exploration for how species respond to distinct oceanographic

69 regimes along the Chilean coast. 
71 Evaluating broad-scale diversity structure on the Chilean coast is of key interest as there

72 are so many oceanographic and biogeographic comparisons to be made between this well-

73 studied coastline and the well-studied Pacific coast of North America (Navarrete et al.

74 2008). However, until recently there were few data available for species that spanned most

75 of the length of the Chilean coastline. This scale is of interest because it spans two major

76 biogeographic transitions - the region around $30^{\circ} \mathrm{S}$ noted above, as well as a notable

77 biogeographic transition near $42^{\circ} \mathrm{S}$ (Thiel et al. 2007). While the divergence of taxa near

$7830^{\circ} \mathrm{S}$ is typically associated with shifts in upwelling and concomitant environmental

79 transitions (Ewers-Saucedo et al. 2016; Haye et al. 2014), the biogeographic transition at

$8042^{\circ} \mathrm{S}$ is more likely driven by divergent current flow (Ewers-Saucedo et al. 2016).

81 Temperature and salinity both exhibit significant transitions along this coastal region

82 (Acha et al. 2004), and thus the dominant biogeographic boundary along the Chilean coast

83 is at about $42^{\circ} \mathrm{S}$ (Thiel et al. 2007).

84

85 Some of the first such work at this spatial scale was done in the direct-developing

86 gastropod Acanthina monodon (Sanchez et al. 2011) and another gastropod Concholepas

87 concholepas (Cardenas et al. 2009). In Acanthina, which has low dispersal potential among

88 locations, strong concordance of intraspecific diversity with the $30^{\circ} \mathrm{S}$ biogeographic

89 boundary was found, but association with the $42^{\circ}$ boundary was less clear. Nevertheless,

90 statistically significant genetic structure and shifts in phenotypic diversity are associated

91 with this region. The gastropod Concholepas concholepas, on the other hand, has high

92 potential for pelagic larval dispersal, is similarly distributed along the coast of Chile, but 
93 exhibits no significant genetic structure at all (Cardenas et al. 2009). These contrasts are

94 wholly in line with predictions based on larval life history.

95

96 Recently, large data sets have become available for other commonly encountered taxa in

97 the Chilean intertidal. Microsatellite data were analyzed in the mussel Perumytilus

98 purpuratus (Guiñez et al. 2016), which both spawns gametes and has a long-lived

99 planktotrophic larva, and this ecosystem engineer exhibited significant structure with two

100 main lineages (separated at approximately $40^{\circ} \mathrm{S}$ ) and isolation by distance within each

101 lineage. Similarly, Ewers-Saucedo et al. (2016) explored genetic variation in the high

102 intertidal barnacle Notochthamalus scabrosus, with nauplius larvae that have high pelagic

103 larval dispersal potential, and found two primary lineages that mirror the dominant

104 biogeographical pattern of Chile: in the northern Peruvian region only one lineage is found,

105 while both are found in the Intermediate Area that represents the overlap of the Peruvian

106 and Magellanic regions, and only the southern lineage is found south of $42^{\circ} \mathrm{S}$. Another

107 barnacle, the edible picoroco (Austromegabalanus psittacus) exhibits only slight structure

108 along most of the Chilean coast (Pappalardo et al. 2016), but nevertheless the observed

109 structure is statistically significant and seems to be associated with the northern $\left(30^{\circ} \mathrm{S}\right)$

110 biogeographic transition.

111

112 To these data we add one more layer: Zakas et al. (2009) had explored mitochondrial

113 sequence population structure in the high intertidal barnacle Jehlius cirratus, a species that

114 is biologically and ecologically very similar to Notochthamalus but found slightly higher in

115 the intertidal (Lamb et al. 2014; Shinen \& Navarrete 2010, 2014). Zakas et al. (2009) found 
116 that unlike Notochthamalus, there was very little apparent genetic structure in J. cirratus.

117 However, that analysis comprised only a small section of the Chilean coast, from $\sim 28-34^{\circ} \mathrm{S}$.

118 Here, we expand the sampling of J. cirratus to include diversity from $\sim 3500 \mathrm{~km}$ of coastline,

119 including most of the known distribution (Häussermann \& Försterra 2009). As chthamalid

120 barnacles have a propensity to harbor cryptic genetic diversity (Dando \& Southward 1981;

121 Meyers et al. 2013; Tsang et al. 2008; Wares et al. 2009; Zardus \& Hadfield 2005), we

122 specifically look for any phylogeographic structure that may add to our understanding of

123 coastal biodiversity in Chile. We then more directly compare the whole-coast data

124 described above for the ecological implications of the population structure identified

125 within and among taxa.

126

127 


\section{Methods}

129 Specimens of J. cirratus were collected from the intertidal in 2004-2013. Field permits were

130 not required from the Subsecretaría de Pesca y Acuicultura for the specimens included in

131 this paper, as they were not "shellfish resources". Sequences of cytochrome oxidase I

132 (n=153) from Zakas et al (2009) were used in this study (Genbank GU126073 -

133 GU126226); additional sequences ( $\mathrm{n}=187)$ were generated from subsequent samples

134 collected in 2011-2013 using PCR methods as in Zakas et al. (2009). Samples were mostly

135 collected in central Chile (Table 1), but this additional effort also added substantially to

136 information from northern Chile and northern Patagonia.

137 After quality control and alignment of sequence data using CodonCode Aligner v6.0.2

138 (CodonCode Corporation), data were formatted for analysis using Arlequin v3.5.2.2.

139 (Excoffier et al. 2005) to identify population structure. Pairwise $\Phi_{\mathrm{ST}}$ was calculated for all

140 sites and compared to a matrix of pairwise geographic distance for signal of isolation by

141 distance (Wright 1943); this was done both with haplotypic data as well as nucleotide data

142 under a K2P distance model. Additionally, an exact test of differentiation was calculated for

143 all pairs of populations. Analysis of molecular variance (AMOVA) was performed to identify

144 maximal structure along the coast as in Dupanloup et al. (2002) and Zakas et al (2009),

145 using an iterative approach for $\mathrm{K}$ contiguous spatial groups, increasing $\mathrm{K}$ if there were

146 significant patterns of $\Phi_{\text {SC }}$ within the determined regional groups. Following the results of

147 AMOVA, a haplotype network was generated using PopArt (http://popart. otago.ac.nz).

148 Haplotypes were coded by sample location and by regions separated by the iterative

149 AMOVA results that maximize $\Phi_{\mathrm{CT}}$ to visually identify components of diversity associated 
150 with each regional group. Population diversity was also assessed at each sampled location;

151 nucleotide diversity $(\pi)$ and haplotype diversity $(H)$ are estimated at each location using

152 Arlequin.

\section{Results}

154 New sequences were archived in GenBank under accession numbers KX014910 -

155 KX015034. Site-specific diversity is presented in Table 1; pairwise values of $\Phi_{\text {ST }}$ are

156 presented in Table 2. Only a single sequence was recovered from the northernmost

157 collection site of Arica, so this sequence was included in the Antofagasta sample (results

158 identical when excluded) for statistical purposes. Values of $\Phi_{S T}$ were very low and in

159 general not statistically significant (Table 2); the only exceptional locations were

160 Guanaqueros $\left(30^{\circ} \mathrm{S}\right)$ and Pichilemu $\left(34^{\circ} \mathrm{S}\right)$, each of which tended to exhibit higher

161 differentiation from a broader set of other locations. No population pairs were significantly

162 different under an exact test. Testing these results for a pattern of genetic isolation by

163 distance was not significant ( $\mathrm{p}$ 0.245).

164 Although negligible structure was exhibited along the Chilean coast in J. cirratus ( $\Phi_{\text {ST }}$ of -

$1650.019, \mathrm{p} \sim 1$ ), there was statistical regional structure detectable with the increased power

166 of sampling at that scale. Our implementation of spatial AMOVA (Zakas et al. 2009)

167 recovered two contrasts for $\mathrm{K}=2$ regions in which $\Phi_{\mathrm{CT}}>0.035$ and $\mathrm{p}<0.01$, though similar

168 results are found if the separation among regions is near to either of these locations (Table

169 3). These local maxima in $\Phi_{\mathrm{CT}}$ separated Guanaqueros $\left(30^{\circ} \mathrm{S}\right)$ and sites to the north from all

170 locations to the south; and Pichilemu $\left(44^{\circ} \mathrm{S}\right)$ and all sites to the south from all locations to

171 the north. No significant $\Phi_{\mathrm{SC}}$ was exhibited in these comparisons. If $\mathrm{K}=3$ groups are chosen 
172 using these same delineations, $\Phi_{\mathrm{CT}}$ was comparable $(0.03661, \mathrm{p}<0.001)$.

173 From these results, a haplotype network (minimum spanning tree) is presented in Figure 1,

174 showing "northern" diversity (from Guanaqueros northward), "southern" diversity

175 (including Pichilemu and southward sites), and "central" diversity (locations in between),

176 for visualization.

\section{Discussion}

178 As noted in Zakas et al. (2009) there is only slight population structure in J. cirratus.

179 Previous efforts had also noted that using alternate statistics such as Hudson's (Hudson

180 2000) Snn also recovered no signal of structure or pattern of isolation by distance (Wares

181 2014). Here, we identify statistically significant structure that is roughly associated with

182 the $30^{\circ} \mathrm{S}$ biogeographic transition between the Peruvian and "Intermediate" zones, and

183 there may also be structure further south - but not associated with the boundary at $42^{\circ} \mathrm{S}$.

184 Overall, the statistical significance indicated - given that pairwise statistical support was

185 not consistent between permutational tests of $\Phi_{\mathrm{ST}}$ and pairwise exact tests of population

186 differentiation - suggests little actual spatial variation but sufficient sampling to identify

187 the differential representation of regional samples in the 2 dominant haplotypes found

188 (Figure 1). Whether this is an instance of 'eurymixis' (Dawson et al. 2011), an instance

189 where structure may exist but the power to detect it with available markers is insufficient

190 to provide a consistent signal, is unclear. Nevertheless, the same methods have allowed the

191 identification of phylogeographic structure in other species with similar distributions. 
193 Excluding the direct developer $A$. monodon from further consideration, the studies

194 reviewed earlier plus the current study include 5 intertidal species with high larval

195 dispersal potential that are distributed and were analyzed along the length of the Chilean

196 coast. Unfortunately, there is no clear pattern associated with intertidal depth; the species

197 with no or slight population genetic structure (J. cirratus, this study; A. psittacus,

198 Pappalardo et al. 2016; C. concholepas, Cardénas et al. 2009) are in the highest reaches of

199 the intertidal (J. cirratus) as well as the low intertidal (A. psittacus and C. concholepas). The

200 two species that exhibit significant structure, each with two primary lineages and evidence

201 for isolation by distance within each lineage, are in the high-to-middle intertidal ( $N$.

202 scabrosus, Ewers-Saucedo et al. 2016; P. purpuratus, Guiñez et al. 2016).

203

204 Clearly a sample of only 5 taxa is insufficient for statistical consideration. However, what

205 we can indicate is that all 3 barnacles (A. psittacus, J. cirratus, and N. scabrosus) have at least

206 some signal associated with the $30-32^{\circ}$ oceanographic transition in upwelling (Lagos et al.

207 2005; Navarrete et al. 2005); in contrast, the two molluscs, the mussel P. purpuratus and

208 abalone C. concholepas, do not. The association of genetic structure with the southern

209 biogeographic boundary near $42^{\circ} \mathrm{S}$ (Thiel et al. 2007) is far more varied; other taxa with

210 shorter distributional ranges that span this biogeographic transition, such as the mussel

211 Mytilus chilensis, show little spatial structure at mitochondrial or other putatively neutral

212 markers (L. Besch and K. Bockrath, unpublished; Areneda et al. 2016) but can be

213 distinguished among different coastal environments by outlier markers (Araneda et al.

214 2016) and expression profiling (Núñez-Acuña et al. 2012). Ewers-Saucedo et al. (2016)

215 note that environmental transitions and current-mediated larval dispersal in this region, 
216 where trans-oceanic currents are separated as they reach the continental margin (Acha et

217 al. 2004), are likely to transport regionally-differentiated diversity along a broad swath of

218 this coastline. Thus, identifying concordant intraspecific diversity patterns among taxa may

219 require a different analytical approach that is model-driven as in Ewers-Saucedo et al.

220 (2016).

221

222 There is an expanding interest in exploration of genetic diversity within and among

223 regional populations of intertidal species along the coast of Chile (see Haye et al. 2014 for a

224 recent synthesis). Such data are being used to explore the underlying causes of

225 biogeographic transition (Cardenas et al. 2009; Ewers-Saucedo et al. 2016), to inform

226 management and aquacultural concerns (Haye \& Munoz-Herrera 2013; Núñez-Acuña et al.

227 2012; Pappalardo et al. 2016), and better understand how the dynamics of a coastal ocean

228 influence local diversity (Aiken \& Navarrete 2014; Broitman et al. 2001; Hinojosa et al.

229 2006; Navarrete et al. 2005). For example, even with variation among the data and taxa

230 evaluated here, there is a concordance between the genetic transitions exhibited in these

231 taxa and regions of strong upwelling along coastal Chile (Navarrete et al. 2005).

232 What remains unsatisfying is our ability to predict - based on what we know of life history,

233 ecology, and other parameters of a given taxon - which species are likely to exhibit

234 structure across a certain region, or why some species are able to spread across boundaries

235 that others cannot (Dawson 2014). Haydon et al. (1994) first noted the problem of both

236 stochastic and deterministic contributions to biogeography and overall population

237 structure. Certainly some 'significant' phylogeographic structure may simply represent the

238 interaction of genealogical processes and modest limitations on gene flow (Irwin 2002). 
239 However, the most direct contrast of the taxa included here involves the barnacles $N$.

240 scabrosus and J. cirratus, which are ecologically nearly indistinguishable (Lamb et al. 2014;

241 Shinen \& Navarrete 2010, 2014) with little known distinction in larval life history. In fact,

242 though $N$. scabrosus exhibits significant phylogeographic structure (Ewers-Saucedo et al.

243 2016), the larvae of $N$. scabrosus appear to require longer times in the plankton and longer

244 times for cyprid metamorphosis than J. cirratus (Venegas et al. 2000). Whether the cause

245 for this contrast in population structure across a large geographic range is ecological,

246 physiological, or simply chance remains unclear.

247

248

\section{Acknowledgments}

250 The author would like to thank Sergio Navarrete, John Binford, Christina Zakas, Leah Besch, 251 Jenna Shinen, Arnaldo Vilaxa Olcay, Daniel Saucedo, Ulo Pörschmann, and Christine Ewers-

252 Saucedo for assistance in collecting specimens and sequence data. Karen Bobier, Paula

253 Pappalardo, Katie Bockrath, Leah Besch, and Bud Freeman assisted with preparation of the 254 manuscript.

255

256 


\section{Literature Cited}

258

259

260

261

262

263

264

265

266

267

268

269

270

271

272

273

274

275

276

277

278

279

280

281

282

283

284

285

286

287

288

289

290

291

292

293

294

295

296

297

298

299
Acha EM, Mianzan HW, Guerrero RA, Favero M, Bava J (2004) Marine fronts at the continental shelves of austral South America: Physical and ecological processes. J. Marine Systems 44, 83-105.

Aiken CM, Navarrete SA (2014) Coexistence of competitors in marine metacommunities: environmental variability, edge effects, and the dispersal niche. Ecology 95, 22892302.

Altman S, Robinson JD, Pringle JM, Byers JE, Wares JP (2013) Edges and overlaps in Northwest Atlantic phylogeography. Diversity 5, 263-275.

Brante A, Fernandez M, Viard F (2012) Phylogeography and Biogeography Concordance in the Marine Gastropod Crepipatella dilatata (Calyptraeidae) along the Southeastern Pacific Coast. Journal of Heredity 103, 630-637.

Broitman BR, Navarrete SA, Smith F, Gaines SD (2001) Geographic variation in southern Pacific intertidal communities. Marine Ecology Progress Series 224, 21-34.

Cardenas L, Castilla JC, Viard F (2009) A phylogeographical analysis across three biogeographical provinces of the south-eastern Pacific: the case of the marine gastropod Concholepas concholepas. Journal of Biogeography 36, 969-981.

Dando PR, Southward AJ (1981) Existence of Atlantic and Mediterranean Forms of Chthamalus-Montagui (Crustacea, Cirripedia) in the Western Mediterranean. Marine Biology Letters 2, 239-248.

Dawson MN (2001) Phylogeography in coastal marine animals: a solution from California? J. Biogeography 28, 723-736.

Dawson MN (2014) Biogeography and complex traits: dispersal syndromes, in the sea. Frontiers of Biogeography 6, 11-15.

Dawson MN, Barber PH, Gonzalez-Guzman LI, Toonen RJ, Dugan JE, Grosberg RK (2011) Phylogeography of Emerita analoga (Crustacea, Decapoda, Hippidae), an eastern Pacific Ocean sand crab with long-lived pelagic larvae. Journal of Biogeography 38, 1600-1612.

Dawson MN, Grosberg RK, Stuart YE, Sanford E (2010) Population genetic analysis of a recent range expansion: mechanisms regulating the poleward range limit in the volcano barnacle Tetraclita rubescens. Molecular Ecology 19, 1585-1605.

Dawson MN, Louie KD, Barlow M, Jacobs DK, Swift CC (2002) Comparative phylogeography of sympatric sister species, Clevelandia ios and Eucyclogobius newberryi (Teleostei, Gobiidae), across the California Transition Zone. Molecular Ecology 11, 1065-1075.

Díaz-Ferguson E, Robinson JD, Silliman BR, Wares JP (2009) Comparative Phylogeography of East Coast American Salt Marsh Communities. Estuaries \& Coasts DOI 10.1007/s12237-009-9220-6.

Dupanloup I, Schneider S, Excoffier L (2002) A simulated annealing approach to define the genetic structure of populations. Mol. Ecol. 11, 2571-2581.

Ewers-Saucedo C, Pringle JM, Sepúlveda HH, Byers JE, Navarrete SA, Wares JP (2016) The oceanic concordance of phylogeography and biogeography: a case study in Notochthamalus. Ecology and Evolution 6, 4403-4420. 
300

301

302

303

304

305

306

307

308

309

310

311

312

313

314

315

316

317

318

319

320

321

322

323

324

325

326

327

328

329

330

331

332

333

334

335

336

337

338

339

340

341

342

343

Excoffier L, Laval G, Schneider S (2005) Arlequin ver. 3.0: An integrated software package for population genetics data analysis. Evolutionary Bioinformatics Online 1, 47-50.

Guiñez R, Pita A, Pérez M, Briones C, Navarrete SA, Toro JE, Presa P (2016) Present-day connectivity of historical stocks of the ecosystem engineer Perumytilus purpuratus along $4500 \mathrm{~km}$ of the Chilean Coast. Fisheries Research 7/16, 322-332.

Häussermann V, Försterra G (2009) Marine Benthic Fauna of Chilean Patagonia Nature in Focus, Santiago, Chile.

Haydon DT, Crother BI, Pianka ER (1994) New directions in biogeography? Trends in Ecology and Evolution 9, 403-406.

Haye PA, Munoz-Herrera NC (2013) Isolation with differentiation followed by expansion with admixture in the tunicate Pyura chilensis. BMC Evol Biol 13, 252.

Haye PA, Segovia NI, Munoz-Herrera NC, Galvez FE, Martinez A, Meynard A, PardoGandarillas MC, Poulin E, Faugeron S (2014) Phylogeographic structure in benthic marine invertebrates of the southeast Pacific coast of Chile with differing dispersal potential. PLos One 9, e88613.

Hinojosa I, Boltana S, Lancellotti D, Macaya E, Ugalde P, Valdivia N, Vasquez N, Newman WA, Thiel M (2006) Geographic distribution and description of four pelagic barnacles along the south east Pacific coast of Chile - a zoogeographical approximation. Revista Chilena de Historia Natural 79, 13-27.

Hudson RR (2000) A new statistic for detecting genetic differentiation. Genetics 155, 20112014.

Hugall A, Moritz C, Moussalli A, Stanisic J (2002) Reconciling paleodistribution models and comparative phylogeography in the Wet Tropics rainforest land snail Gnarosophia bellendenkerensis (Brazier 1875). Proceedings Of The National Academy Of Sciences Of The United States Of America 99, 6112-6117.

Irwin DE (2002) Phylogeographic breaks without geographic barriers to gene flow. Evolution 56, 2383-2394.

Kelly RP, Palumbi SR (2010) Genetic structure among 50 species of the northeastern Pacific rocky intertidal community. PLos One 5, e8594.

Lagos NA, Navarrete SA, Véliz F, Masuero A, Castilla JC (2005) Meso-scale spatial variation in settlement and recruitment of intertidal barnacles along the coast of central Chile. Mar. Ecol. Prog. Ser. 290, 165-178.

Lamb EA, Leslie HM, Shinen JL (2014) Both like it hot? Influence of temperature on two cooccurring intertidal barnacles in central Chile. Journal of Experimental Marine Biology and Ecology 453, 54-61.

Marko PB (2004) 'What's larvae got to do with it?' Disparate patterns of post-glacial population structure in two benthic marine gastropods with identical dispersal potential. Molecular Ecology 13, 597-611.

Meyers M, Pankey MS, Wares JP (2013) Genealogical approaches to the temporal origins of the Central American Gap: Speciation and divergence in Pacific Chthamalus. Revista Biologia Tropical 61, 75-88.

Navarrete SA, Broitman BR, Menge BA (2008) Interhemispheric comparison of recruitment to rocky intertidal communities: pattern persistence and scales of variation. Ecology 89, 1308-1322. 
344 Navarrete SA, Wieters EA, Broitman BR, Castilla JC (2005) Scales of benthic-pelagic

345

346

347

348

349

350

351

352

353

354

355

356

357

358

359

360

361

362

363

364

365

366

367

368

369

370

371

372

373

374

375

376

377

378

379

380

381

382

383

384

385

386

387

388

389 coupling and the intensity of species interactions: From recruitment limitation to top-down control. PNAS 102, 18046-18051.

Núñez-Acuña G, Tapia FJ, Haye PA, Gallardo-Escárate C (2012) Gene expression analysis in Mytilus chilensis populations reveals local patterns associated with ocean environmental conditions. J. exp. mar. Biol. Ecol. 420-421, 56-64.

Pappalardo P, Pitombo FB, Haye PA, Wares JP (2016) A Rose by Any Other Name: Systematics and Diversity in the Chilean Giant Barnacle Austromegabalanus Psittacus (Molina, 1782) (Cirripedia). Journal of Crustacean Biology 36, 180-188.

Pelc RA, Warner RR, Gaines SD (2009) Geographical patterns of genetic structure in marine species with contrasting life histories. J. Biogeogr. 36, 1881-1890.

Riginos C, Nachman MW (2001) Population subdivision in marine environments: the contributions of biogeography, geographical distance and discontinuous habitat to genetic differentiation in a blennioid fish, Axoclinus nigricaudus. Mol Ecol 10, 14391453.

Rocha-Olivares A, Vetter RD (1999) Effects of oceanographic circulation on the gene flow, genetic structure, and phylogeography of the rosethorn rockfish (Sebastes helvomaculatus). Canadian Journal of Fisheries and Aquatic Sciences 56, 803-813.

Sanchez R, Sepulveda RD, Brante A, Cardenas L (2011) Spatial pattern of genetic and morphological diversity in the direct developer Acanthina monodon (Gastropoda: Mollusca). Marine Ecology Progress Series 434, 121-131.

Shinen JL, Navarrete SA (2010) Coexistence and intertidal zonation of chthamalid barnacles along central Chile: Interference competition or a lottery for space? Journal of Experimental Marine Biology and Ecology 392, 176-187.

Shinen JL, Navarrete SA (2014) Lottery coexistence on rocky shores: Weak niche differentiation or equal competitors engaged in neutral dynamics? American Naturalist 183, 342-362.

Small ST, Wares JP (2010) Phylogeography and marine retention. Journal of Biogeography 37, 781-784.

Sotka EE, Wares JP, Barth JA, Grosberg RK, Palumbi SR (2004) Strong genetic clines and geographical variation in gene flow in the rocky intertidal barnacle Balanus glandula. Molecular Ecology 13, 2143-2156.

Stuart-Fox DM, Schneider CJ, Moritz C, Couper PJ (2001) Comparative phylogeography of three rainforest-restricted lizards from mid-east Queensland. Australian Journal of Zoology 49, 119-127.

Sullivan J, Arellano E, Rogers DS (2000) Comparative phylogeography of Mesoamerican highland rodents: concerted versus independent response to past climatic fluctuations. The American Naturalist 155, 755-768.

Thiel M, Macaya E, Acuna E, Arntz W, Bastias H, Brokordt K, Camus P, Castilla J, Castro L, Cortes M, Dumont C, Escribano R, Fernandez M, Gajardo J, Gaymer C, Gomez I, Gonzalez A, Gonzalez H, Haye P, Illanes J, Iriarte J, Lancellotti D, Luna-Jorquerai G, Luxoroi C, Manriquez P, Marin V, Munoz P, Navarrete S, Perez E, Poulin E, Sellanes J, Sepulveda H, Stotz W, Tala F, Thomas A, Vargas C, Vasquez J, Vega J (2007) The Humboldt Current System of northern and central Chile CRC Press, Boca Raton, FL.

Tsang LM, Chan BKK, Wu TH, Ng WC, Chatterjee T, Williams GA, Chu KH (2008) Population differentiation in the barnacle Chthamalus malayensis: postglacial colonization and 
390

391

392

393

394

395

396

397

398

399

400

401

402

403

404

405

406

407

408

409

410

411

412

413

414

415

416

recent connectivity across the Pacific and Indian Oceans. Mar. Ecol. Prog. Ser. 364, 107-118.

Venegas RM, Ortiíz V, Olguín A, Navarrete SA (2000) Larval development of the intertidal barnacles Jehlius cirratus and Notochthamalus scabrosus (Cirripedia: Chthamalidae) under laboratory conditions. J. Crust. Biol. 20, 495-504.

Wares JP (2002) Community genetics in the Northwestern Atlantic intertidal. Molecular Ecology 11, 1131-1144.

Wares JP (2014) Why not do phylogeography on every chthamalid barnacle? The case of Jehlius cirratus. PeerJ PrePrints 2, e596v592.

Wares JP (2016) Population structure and gene flow. In: Encyclopedia of Evolutionary Biology (ed. Kliman RM), pp. 327-331. Academic Press, Oxford.

Wares JP, Castañeda AE (2005) Geographic range in Chthamalus along the west coast of North America. J. mar. biol. Ass. U.K. 85, 327-331.

Wares JP, Gaines SD, Cunningham CW (2001) A comparative study of asymmetric migration events across a marine biogeographic boundary. Evolution 55, 295-306.

Wares JP, Pankey MS, Pitombo FB, Gómez Daglio LE, Achituv Y (2009) A "shallow phylogeny" of shallow barnacles (Chthamalus). PLos One 4, e5567.

Wright S (1943) Isolation by distance. Genetics 28, 139-156.

Zakas C, Binford J, Navarrete SA, Wares JP (2009) Restricted gene flow in Chilean barnacles reflects an oceanographic and biogeographic transition zone. Marine Ecology Progress Series 394, 165-177.

Zardus JD, Hadfield MG (2005) Multiple origins and incursions of the Atlantic barnacle Chthamalus proteus in the Pacific. Molecular Ecology 14, 3719-3733. 
Table 1 Collection sites, number of individuals per sampling site (n) and summary statistics of

420 genetic variability for Jehlius cirratus.

421

\begin{tabular}{|l|l|l|l|l|}
\hline Site (South Latitude) & sampled & haplotypes & $\begin{array}{l}\text { haplotype } \\
\text { diversity }\end{array}$ & $\begin{array}{l}\text { nucleotide } \\
\text { diversity }(\boldsymbol{\pi})\end{array}$ \\
\hline Antofagasta/Arica $\left(18.49^{\circ}\right)$ & 31 & 27 & $0.978 \pm 0.020$ & $0.012 \pm 0.009$ \\
\hline Huasco $\left(28.46^{\circ}\right)$ & 41 & 25 & $0.945 \pm 0.022$ & $0.009 \pm 0.003$ \\
\hline Temblador $\left(29.40^{\circ}\right)$ & 21 & 16 & $0.948 \pm 0.040$ & $0.009 \pm 0.006$ \\
\hline Guanaqueros $\left(30.20^{\circ}\right)$ & 24 & 18 & $0.942 \pm 0.040$ & $0.011 \pm 0.006$ \\
\hline Punta Talca $\left(30.95^{\circ}\right)$ & 23 & 14 & $0.893 \pm 0.052$ & $0.008 \pm 0.004$ \\
\hline Los Molles $\left(32.25^{\circ}\right)$ & 28 & 23 & $0.971 \pm 0.024$ & $0.011 \pm 0.007$ \\
\hline Monte Mar $\left(32.95^{\circ}\right)$ & 28 & 24 & $0.987 \pm 0.014$ & $0.011 \pm 0.006$ \\
\hline El Quisco $\left(33.45^{\circ}\right)$ & 29 & 25 & $0.988 \pm 0.013$ & $0.010 \pm 0.006$ \\
\hline Las Cruces $\left(33.49^{\circ}\right)$ & 17 & 16 & $0.993 \pm 0.023$ & $0.012 \pm 0.006$ \\
\hline Matanzas $\left(33.95^{\circ}\right)$ & 24 & 20 & $0.975 \pm 0.024$ & $0.011 \pm 0.006$ \\
\hline Pichilemu $\left(34.42^{\circ}\right)$ & 32 & 24 & $0.958 \pm 0.025$ & $0.010 \pm 0.008$ \\
\hline Niebla $\left(39.85^{\circ}\right)$ & 25 & 17 & $0.957 \pm 0.024$ & $0.014 \pm 0.008$ \\
\hline Añihue $\left(43.85^{\circ}\right)$ & 8 & 7 & $0.964 \pm 0.077$ & $0.016 \pm 0.009$ \\
\hline Isla Madre de Dios $\left(50.42^{\circ}\right)$ & 7 & 3 & $0.667 \pm 0.160$ & $0.009 \pm 0.004$ \\
\hline
\end{tabular}


424 Table 2 Pairwise $\Phi_{\mathrm{ST}}$ values among sites (indicated as header) for mitochondrial COI sequence data in Jehlius cirratus. 425 Statistically significant $(\mathrm{p}<0.01)$ comparisons are bolded and in blue. The sample from Antofagasta includes the single 426 available sequence from Arica.

$\begin{array}{lllll}-0.03313 & -0.0885 & 0.01678 & -0.04187 & -0.04029\end{array}$

$\begin{array}{lllll}-0.01175 & 0.02556 & -0.00176 & 0.07232 & -0.03869\end{array}$

\begin{tabular}{|c|c|c|c|}
\hline-0.0777 & 0.01877 & -0.04544 & 0.08615 \\
\hline
\end{tabular}

-0.04482
0.085

0.085
-0.02781

-0.02781
0.00933

$-0.0131$

$-0.02592$

$-0.01377 \quad-0.10077$

$-0.09641 \quad-0.21442$

$-0.03799-0.02988$

$\begin{array}{lll}-0.08512 & 0.04286 & -0.00793\end{array}$

-0.07314
0.04336
-0.03887
-0.04939
-0.07119

-0.02223
-0.10159
0.00464
0.03113

$-0.01699$

0.02127

$-0.09806$

$-0.05271$

$-0.13056$

0.04426 
431 Table 3 Iterative AMOVA for $\mathrm{K}=2$ regions of sequence diversity. Site is listed as dividing 432 that location and all sites to the north from all locations to the south. The northernmost 2 433 sites (Arica, Antofagasta) were pooled for analysis as were the southernmost 2 sites 434 (Añihue, Madre de Dios). Strongest values of $\Phi_{\mathrm{CT}}$ (by magnitude and p-value) indicated in 435 bold. Similar value of $\Phi_{\text {Ст }}(0.0366, p<0.001)$ is obtained with $\mathrm{K}=3$ and the regions 436 separated as in Figure 1.

437

\begin{tabular}{|l|l|l|}
\hline Site & $\Phi_{\mathrm{CT}}$ & p-value \\
\hline Huasco & 0.01406 & 0.16 \\
\hline Temblador & 0.01977 & 0.11 \\
\hline Guanaqueros & $\mathbf{0 . 0 3 6 7 9}$ & $<\mathbf{0 . 0 0 1}$ \\
\hline Punta Talca & 0.02623 & 0.03 \\
\hline Los Molles & 0.03215 & $<0.01$ \\
\hline Monte Mar & 0.02998 & 0.01 \\
\hline El Quisco & 0.02896 & $<0.01$ \\
\hline Las Cruces & 0.03463 & $<0.01$ \\
\hline Matanzas & $\mathbf{0 . 0 3 6 1 5}$ & $<\mathbf{0 . 0 0 5}$ \\
\hline Pichilemu & 0.00076 & 0.55 \\
\hline Niebla & 0.00635 & 0.64 \\
\hline
\end{tabular}


443

Figure 1. Minimum-spanning tree of mitochondrial COI diversity in Jehlius cirratus. Regional designations are generated from 448

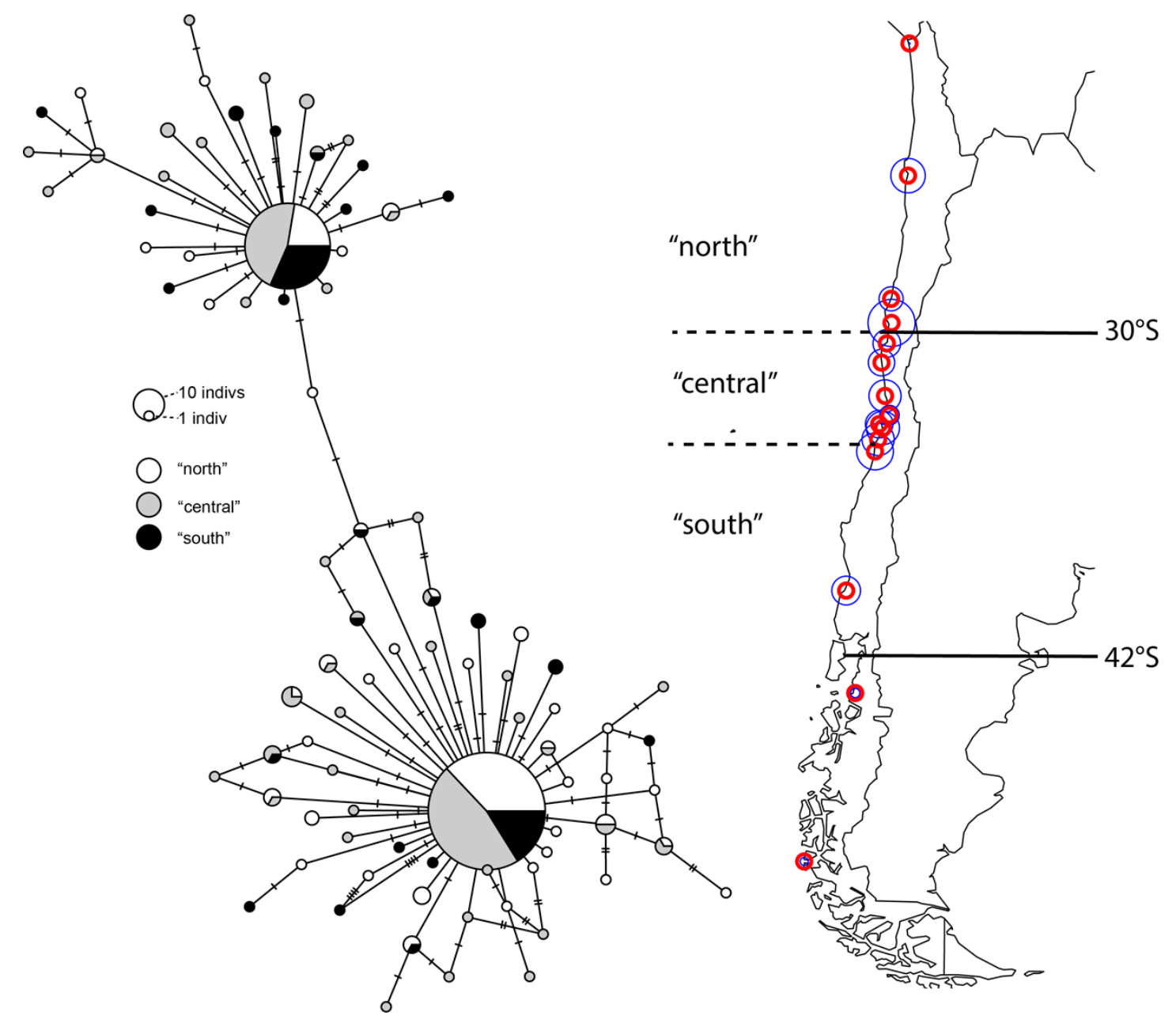

maximal $\Phi_{\mathrm{CT}}$ values along the coast. Map to right of figure indicates the hypothesized transitions of species and genetic diversity noted from previous work $\left(30^{\circ} \mathrm{S}, 42^{\circ} \mathrm{S}\right)$ and the regional separation of diversity supported by analyses of molecular 
449 variance in this study ("north", "central", and "south"). Red circles indicate sample locations along the coast; blue circles 450 represent log-transformed sample size (see Table 1). 